\title{
The Core Values of Information Literacy in the Ubiquitous Information Society
}

\author{
Siu Cheung Kong, Department of Information and Applied Technology, \\ The Hong Kong Institute of Education, Hong Kong \\ Fong Lok Lee, Department of Curriculum and Instruction, \\ The Chinese University of Hong Kong, Hong Kong \\ Siu Cheung Li, Department of Education Studies, \\ Hong Kong Baptist University, Hong Kong \\ Sandra Lee, Faculty of Education, \\ The University of Hong Kong, Hong Kong,
}

\begin{abstract}
This research aims to study the perception of school practitioners on the core values of information literacy in the ubiquitous information society. An information literacy framework has been proposed that includes four dimensions and eleven derived standards. Seventeen focus group discussion sessions were conducted to gain an understanding of the views of school practitioners. The research findings show that information literacy education should be designed with the humanistic rationale of guiding learners to develop information processing skills, which requires both cognitive capability and the associated affective elements. Students should further develop in the meta-cognitive and socio-cultural domains.
\end{abstract}

\section{Introduction}

Information technology (IT) in education for students in the twenty-first century is motivated by three developments. First, the new knowledge society requires students to acquire the ability to process information to respond to the exponential growth of knowledge since the twentieth century. Second, the growing popularity of a digital culture has created a necessity for learners to be equipped with skills in information and communication technology, in response to the digitalisation across industries that has occurred since the mid-twentieth century. Thirdly, due to the globalisation of the world economy, students should develop a global perspective, value community and communicate and cooperate with people from different cultural backgrounds.

The ubiquitous information society is one in which information, as exemplified by the Internet, can be accessed by anyone, anytime, anywhere. This society is one in which people are surrounded by computing devices, networks, applications, and services. "The term 'ubiquitous society' is defined as a society in which people can access a network anytime, anywhere, and for anything” (Tomonori, 2004, I1). Learners should undergo continuous independent learning to gain new knowledge in problem solving and cultivate their ability to process information, which is essential for learning to learn.

The Education and Manpower Bureau of the Hong Kong SAR Government issued the document "Empowering Learning and Teaching with Information Technology", which details the focus of the next education strategy to 
guide practitioners on the integration of IT into learning and teaching, and the development of learners in the lifelong learning of skills, knowledge, and attitudes (Education and Manpower Bureau, 2004). To achieve this, the Education and Manpower Bureau proposed “a broad framework of 'information literacy' for students will be developed to help teachers and students have a clearer picture on the learning targets of using IT in education” (Education and Manpower Bureau, 2004, p. 13).

An information-literate person in the ubiquitous information society should know how to determine the nature and extent of the information that is needed, how to find information effectively and efficiently, and how to use information to gain an understanding of the economic, legal and social issues that surround the use of information. The aim of this study is to understand the perception of school practitioners regarding the core values of information literacy in this context.

\section{Background of the Study}

The ongoing and unprecedented growth of information and communications technology, coupled with the globalisation of the economy, has created a huge challenge for education. The pursuit of information literacy in education has become widespread with the pervasiveness of global networks. Information literacy education can thus be seen as a way to address the growing awareness and demand for preparing students to effectively participate in the emerging global knowledge economy. Bates (2000) contends that to struggle against social exclusion and to maintain competitiveness in a global economy, education must go beyond the framework of initial schooling to prepare and support citizens for lifelong learning (Hargreaves, 2004).

The World Summit on the Information Society in 2003 also stated that "each person should have the opportunity to acquire the necessary skills and knowledge in order to understand, participate actively in, and benefit fully from, the Information Society and the knowledge economy" (World Summit on the Information Society, 2003, para. 29). Capacity building refers to an ongoing process of developing in a learner the capacity to work both independently and socially, and to participate in, benefit from and contribute to the knowledge society and the wider global community.

Information literacy is the ability to master the processes of becoming informed, and is an essential capability that is needed by citizens to adapt to digital culture, globalisation and the emerging knowledge-based society. Therefore, information literacy in Hong Kong should be framed in such a way that students are empowered with the capacity for lifelong learning, and assume greater autonomy over and social responsibility for their learning. In its document entitled "A Study on the Development of an Information Literacy Framework for Hong Kong Students" we proposed 11 information literacy standards in four dimensions: cognitive, metacognitive, affective and socio-cultural (Education and Manpower Bureau, in press). Table 1 illustrates these standards. 
Table 1: Information literacy standards in four dimensions: cognitive (C), metacognitive (M), affective (A) and socio-cultural (S)

\begin{tabular}{|c|c|}
\hline Code & Information literacy standards \\
\hline C1 & $\begin{array}{l}\text { An information literate person is able to determine the extent of and locate the information } \\
\text { needed. }\end{array}$ \\
\hline C2 & $\begin{array}{l}\text { An information literate person is able to apply information to problem solving and decision } \\
\text { making. }\end{array}$ \\
\hline C3 & $\begin{array}{l}\text { An information literate person is able to analyse the collected information and construct new } \\
\text { concepts or understandings. }\end{array}$ \\
\hline $\mathrm{C} 4$ & $\begin{array}{l}\text { An information literate person is able to critically evaluate information and integrate new } \\
\text { concepts with prior knowledge. }\end{array}$ \\
\hline M1 & $\begin{array}{l}\text { An information literate person is aware that information processing is iterative, time- } \\
\text { consuming and demands effort. }\end{array}$ \\
\hline M2 & An information literate person is able to plan and monitor the process of inquiry. \\
\hline M3 & An information literate person is able to reflect upon and regulate the process of inquiry. \\
\hline A1 & $\begin{array}{l}\text { An information literate person is able to recognise that being an independent reader will } \\
\text { contribute to personal enjoyment and lifelong learning. }\end{array}$ \\
\hline A2 & $\begin{array}{l}\text { An information literate person is able to recognise that information processing skills and } \\
\text { freedom of information access are pivotal to sustaining the development of a knowledge } \\
\text { society. }\end{array}$ \\
\hline S1 & $\begin{array}{l}\text { An information literate person is able to contribute positively to the learning community in } \\
\text { knowledge building. }\end{array}$ \\
\hline S2 & $\begin{array}{l}\text { An information literate person is able to understand and respect the ethical, legal, political } \\
\text { and cultural contexts in which information is being used. }\end{array}$ \\
\hline
\end{tabular}

\section{Research Methodology}

Seventeen focus group discussion sessions, which include participants from education associations, education bodies, IT pilot primary and secondary schools in 1998, secondary, primary and international schools, and expert panels on information literacy, were conducted from November 2004 to February 2005. Nine groups of primary and secondary schools were involved, which covered five districts, namely, New Territories East, New Territories North, New Territories West, Kowloon and Hong Kong Island. Ten primary and ten secondary schools were randomly selected in each district. The participants included teachers, teacher-librarians, school principals, and representatives from other professional organisations. Table 1 illustrates the demographic data of the focus group participants. 
Table 1: Demographic data of the focus group participants

\begin{tabular}{l|c|c|c|c|c}
\hline \multicolumn{1}{c|}{$\begin{array}{c}\text { Focus group } \\
\text { categories }\end{array}$} & $\begin{array}{c}\text { No. of } \\
\text { focus } \\
\text { groups }\end{array}$ & $\begin{array}{c}\text { No. of } \\
\text { participants }\end{array}$ & $\begin{array}{c}\text { No. of invited } \\
\text { organizations(y) }\end{array}$ & $\begin{array}{c}\text { No. of } \\
\text { responded } \\
\text { organizations } \\
\text { (x) }\end{array}$ & $\begin{array}{c}\text { Response } \\
\text { Rate(x/y) }\end{array}$ \\
\hline $\begin{array}{l}\text { Education } \\
\text { associations }\end{array}$ & 1 & 8 & 11 & 7 & $63.64 \%$ \\
\hline Education bodies & 1 & 7 & 15 & 7 & $46.67 \%$ \\
\hline Secondary schools & 5 & 22 & 52 & 22 & $42.31 \%$ \\
\hline $\begin{array}{l}\text { IT pilot secondary } \\
\text { schools in 1998 }\end{array}$ & 1 & 7 & 10 & 5 & $50.00 \%$ \\
\hline $\begin{array}{l}\text { Primary schools } \\
\text { IT pilot primary } \\
\text { schools in 1998 }\end{array}$ & 1 & 17 & 56 & 16 & $28.57 \%$ \\
\hline $\begin{array}{l}\text { International } \\
\text { schools }\end{array}$ & 2 & 8 & 10 & 3 & $30.00 \%$ \\
\hline $\begin{array}{l}\text { Expert panels on } \\
\text { information }\end{array}$ & 2 & About 30 & 2 & 6 & $37.50 \%$ \\
\hline literacy & 17 & About 102 & 172 & 68 & $39.53 \%$ \\
\hline Total
\end{tabular}

Each discussion session lasted for approximately one and a half hours. All of the participants were asked to write down their views at the end of the meetings and to answer a questionnaire that probed the importance of the four dimensions in the information literacy framework. Three questions were asked in the focus group meeting: "Is information literacy needed in a society such as Hong Kong for its future development? Why?" "What is your opinion on the core values of information literacy?" and "What standards should be designed in the information literacy framework for Hong Kong students?”. 62 pieces of written feedback and 71 focus group questionnaires were received.

\section{Results and Discussion}

It was evident from the focus group questionnaire and written feedback that the focus of the primary schools and secondary schools on information literacy should differ. The participants regarded cognition to be most important for primary education, but thought that social culture was more important for secondary education. The details are illustrated in Tables 3 to 8 . When participants from the focus group discussions were asked to choose the three most important dimensions for both primary and secondary students, they selected social culture and cognition. The details are illustrated in Table 3. 
Table 3: Frequency of the four dimensions in the choice of the three most important dimensions for both primary and secondary students from the results of focus group questionnaire

\begin{tabular}{l|c|c}
\hline \multicolumn{1}{c|}{ Information literacy dimensions } & Frequency & \% \\
\hline Socio-cultural & 46 & $27.71 \%$ \\
\hline Cognitive & 45 & $27.11 \%$ \\
\hline Affective & 41 & $24.70 \%$ \\
\hline Meta-cognitive & 34 & $20.48 \%$ \\
\hline Total & 166 & $100.00 \%$ \\
\hline
\end{tabular}

In rating the importance of the four dimensions for primary students, the cognitive dimension was given a 3.98 rating on a five-point scale and the affective dimension a 3.76 rating. The participants regarded these dimensions to be significant for primary education. The socio-cultural dimension was given a rating of 4.37 for secondary students, and was regarded to be the most important dimension for secondary education. The details are illustrated in Tables 4 and 5. Generally, the average score for the four dimensions for secondary students is over 4, and the average score for the dimensions for primary students is over 3 but less than 4 . This shows that being information literate is seen as being imperative for both primary and secondary students, but is perceived to be more important for secondary students.

Table 4: Average score on a five-point scale of the importance of the four dimensions for primary students from the results of focus group questionnaire

\begin{tabular}{l|c|c|c}
\hline Information literacy dimensions & Average & Standard Deviation & Total entry \\
\hline Cognitive & 3.98 & 1.04 & 58 \\
\hline Affective & 3.76 & 0.99 & 58 \\
\hline Socio-cultural & 3.40 & 1.15 & 57 \\
\hline Meta-cognitive & 3.29 & 0.98 & 58 \\
\hline
\end{tabular}

Table 5: Average score on a five-point scale of the importance of the four dimensions for secondary students from the results of focus group questionnaire

\begin{tabular}{l|c|c|c}
\hline \multicolumn{1}{c|}{$\begin{array}{c}\text { Information literacy } \\
\text { dimensions }\end{array}$} & Average & Standard Deviation & Total entry \\
\hline Socio-cultural & 4.37 & 0.85 & 57 \\
\hline Cognitive & 4.35 & 0.87 & 57 \\
\hline Affective & 4.28 & 0.87 & 57 \\
\hline Meta-cognitive & 4.21 & 0.88 & 56 \\
\hline
\end{tabular}

Both the cognitive and socio-cultural dimensions were considered to be important for primary and secondary students, and the participants also considered that the focus of both primary and secondary education should be the initial cultivation of the cognitive and affective domains, and that students could further develop the meta-cognitive and socio-cultural domains later.

Therefore, information literacy education should be designed with the humanistic rationale of guiding learners to develop from the acquisition of basic information processing skill through to complex level thinking skills and then to meta-cognitive abilities in an information society, which requires both cognitive 
capabilities and the associated affective elements to be integrated in the learning and application process for the well-being of society (Martin \& Rader, 2003; Riedling, 2002; Rogers \& Freiberg, 1994).

Table 6: Average score on a five-point scale of the importance of the 11 standards for primary students

\begin{tabular}{c|l|c|c|c}
\hline Code & \multicolumn{1}{|c|}{ Information literacy standards } & Average & $\begin{array}{c}\text { Standard } \\
\text { Deviation }\end{array}$ & $\begin{array}{c}\text { Total } \\
\text { entry }\end{array}$ \\
\hline C1 & $\begin{array}{l}\text { Able to determine the extent of and locate the } \\
\text { information needed. }\end{array}$ & 3.85 & 0.90 & 65 \\
\hline C2 & $\begin{array}{l}\text { Able to apply information to problem solving and } \\
\text { decision making. }\end{array}$ & 3.61 & 0.91 & 64 \\
\hline S2 & $\begin{array}{l}\text { Able to understand and respect the moral, legal, } \\
\text { political and cultural contexts in which } \\
\text { information is being used. }\end{array}$ & 3.54 & 1.19 & 65 \\
\hline A2 & $\begin{array}{l}\text { Able to recognise that information processing } \\
\text { skills and freedom of information access are } \\
\text { pivotal to sustaining the development of a } \\
\text { knowledge society. }\end{array}$ & 3.41 & 1.20 & 64 \\
\hline A1 & $\begin{array}{l}\text { Able to recognise that being an independent } \\
\text { reader will contribute to personal enjoyment and } \\
\text { lifelong learning. }\end{array}$ & 3.34 & 1.14 & 65 \\
\hline M1 & $\begin{array}{l}\text { Aware that information processing is iterative, } \\
\text { time-consuming and demands effort. }\end{array}$ & 3.32 & 1.18 & 65 \\
\hline C3 & $\begin{array}{l}\text { Able to analyse the collected information and } \\
\text { construct new concepts or understandings. }\end{array}$ & 3.26 & 1.09 & 65 \\
\hline C4 & $\begin{array}{l}\text { Able to critically evaluate information and } \\
\text { integrate new concepts with prior knowledge. }\end{array}$ & 3.22 & 1.17 & 65 \\
\hline S1 & $\begin{array}{l}\text { Able to contribute positively to the learning } \\
\text { community in knowledge building. }\end{array}$ & 3.17 & 1.10 & 64 \\
\hline M2 & Able to plan and monitor the process of enquiry. & 3.14 & 1.14 & 65 \\
\hline M3 & $\begin{array}{l}\text { Able to reflect upon and regulate the process of } \\
\text { enquiry. }\end{array}$ & 3.12 & 1.16 & 65 \\
\hline
\end{tabular}

In rating the importance of the 11 standards for primary students, two of the top three standards that were rated by the participants were in the cognitive dimension (C1 and $\mathrm{C} 2$ ) and one was in the socio-cultural dimension (S2). This shows that the capability to process information and use the skills of information processing for decision-making and problem solving are considered to be essential for primary students. Table 6 illustrates the average score of the importance of the 11 standards for primary students from the results of the focus group questionnaire. 
Table 7: Average score on a five-point scale of the importance of the 11 standards for secondary students

\begin{tabular}{|c|c|c|c|c|}
\hline Code & Information literacy standards & Average & $\begin{array}{l}\text { Standard } \\
\text { Deviation }\end{array}$ & $\begin{array}{l}\text { Total } \\
\text { entry }\end{array}$ \\
\hline C1 & $\begin{array}{l}\text { Able to determine the extent of and locate the } \\
\text { information needed. }\end{array}$ & 4.52 & 0.79 & 65 \\
\hline $\mathrm{C} 2$ & $\begin{array}{l}\text { Able to apply information to problem solving and } \\
\text { decision-making. }\end{array}$ & 4.43 & 0.78 & 65 \\
\hline C3 & $\begin{array}{l}\text { Able to analyse the collected information and } \\
\text { construct new concepts or understandings. }\end{array}$ & 4.34 & 0.80 & 64 \\
\hline $\mathrm{S} 2$ & $\begin{array}{l}\text { Able to understand and respect the moral, legal, } \\
\text { political and cultural contexts in which } \\
\text { information is being used. }\end{array}$ & 4.34 & 1.00 & 65 \\
\hline $\mathrm{C} 4$ & $\begin{array}{l}\text { Able to critically evaluate information and } \\
\text { integrate new concepts with prior knowledge. }\end{array}$ & 4.32 & 0.83 & 65 \\
\hline A2 & $\begin{array}{l}\text { Able to recognise that information processing } \\
\text { skills and freedom of information access are } \\
\text { pivotal to sustaining the development of a } \\
\text { knowledge society }\end{array}$ & 4.32 & 0.95 & 65 \\
\hline A1 & $\begin{array}{l}\text { Able to recognise that being an independent reader } \\
\text { will contribute to personal enjoyment and lifelong } \\
\text { learning. }\end{array}$ & 4.23 & 0.91 & 65 \\
\hline M2 & Able to plan and monitor the process of enquiry. & 4.12 & 0.95 & 65 \\
\hline M3 & $\begin{array}{l}\text { Able to reflect upon and regulate the process of } \\
\text { enquiry. }\end{array}$ & 4.11 & 0.98 & 65 \\
\hline $\mathrm{S} 1$ & $\begin{array}{l}\text { Able to contribute positively to the learning } \\
\text { community in knowledge building. }\end{array}$ & 4.09 & 0.82 & 65 \\
\hline M1 & $\begin{array}{l}\text { Aware that information processing is iterative, } \\
\text { time-consuming and demands effort. }\end{array}$ & 4.03 & 0.94 & 65 \\
\hline
\end{tabular}

Similarly, for secondary students, the top three standards as rated by the participants were all in the cognitive dimension (C1, C2 and C3), and the fourth most important standard was in the socio-cultural dimension (S2). The average score of the importance of the 11 standards for secondary students is over 4 , and the average score of the importance of the standards for primary students is over 3 but less than 4 . This shows that possessing the 11 abilities is crucial for both primary and secondary students, but is more important for secondary students. Table 7 illustrates the average score of the importance of the 11 standards for secondary students from the results of focus group questionnaire.

The focus group questionnaire and the written feedback show that both the cognitive and socio-cultural dimensions are considered to be important for primary and secondary students. Participants from the focus group discussions regarded the capability to use the skills of information processing for decision-making and problem solving to be an essential ability for both primary and secondary students. However, learners should also be able to understand and respect the moral, legal, political and cultural contexts in which information is being used. Meta-cognitive capability, in the long run, is a vital factor in the development of information literacy in students to help them to adapt to the ever-changing information society. 


\section{Conclusion}

The ubiquitous information society is one in which information, as exemplified by the Internet, can be accessed by anyone, anytime and anywhere, and in which people are surrounded by computing devices, networks, applications and services. An information-literate person in a ubiquitous information society should know how to decide on the extent of information that is needed, how to effectively and efficiently find information and how to use information with an understanding of the many economic, legal, and social issues that surround the use of information.

Henri says information literacy is characterized by the ability "to master the processes of becoming informed.” (Henri, 2005, p. 21) Information literacy is an essential capability that is needed to adapt to digital culture, globalisation and the emerging knowledge-based society. Based on the 11 information literacy standards that have been proposed, 17 focus group discussion sessions were conducted to study the perceptions of school practitioners on the core values of information literacy in the ubiquitous information society.

The focus group questionnaire and written feedback show that both the cognitive and socio-cultural dimensions are considered to be important for primary and secondary students. One of the core values of information literacy is that learners should have the capability to use the skills of information processing, and at the same time be able to understand and respect the moral, legal, political and cultural contexts in which information is being used. In the long run, the meta-cognitive dimension is another crucial area of development for information literacy if people are to adapt to the ubiquitous information society. 


\section{References}

Bates, A. (2000). Managing technological change: Strategies for college and university leaders. San Francisco: Jossey-Bass.

Education and Manpower Bureau. (2004). Empowering learning and teaching with information technology. Hong Kong: Education and Manpower Bureau.

Education and Manpower Bureau. (in press). A study on the development of an information literacy framework for Hong Kong students. Hong Kong: Education and Manpower Bureau.

Hargreaves, D.H. (2004). Learning for life: The foundations for lifelong learning. Bristol: Policy.

Henri, J. (2005). Understanding the information literate school community. In J. Henri and M. Asselin (Eds.) The information literate school community 2: Issues of leadership. (pp. 11-26). Wagga Wagga, NSW: Centre for Information Studies.

Martin, A. and Rader, H. (Eds.) (2003). Information and IT literacy: Enabling learning in the $21^{\text {st }}$ century. London: Facet Publishing.

Riedling, A. M. (2002). Learning to learn: A guide to information literacy. New York: Neal-Schuman Publishers.

Rogers C. R. and Freiberg H. J. (1994). Freedom to learn. New York: Merrill.

Tomonori, A. (2004) Providing Useful Information and Services for the "Here and Now”. Web Magazine Vol.009. Retrieved 14 April 2005, from http://61.195.172.240/ctec4/asp/contents/view/news/webmaga_detail.asp? la=1\&d_id=4933.

World Summit on the Information Society. (2003). Building the information society: a global challenge in the new Millennium. Retrieved 28 January 2005, from http://www.itu.int/dms_pub/itu-s/md/03/wsis/doc/S03-WSIS-DOC0004!!PDF-E.pdf. 
Reproduced with permission of the copyright owner. Further reproduction prohibited without permission. 